\title{
Clinical simulation with dramatization: gains perceived by students and health professionals
}

\author{
Elaine Cristina Negri ${ }^{1}$ \\ Alessandra Mazzo ${ }^{2}$ \\ José Carlos Amado Martins ${ }^{3}$ \\ Gerson Alves Pereira Junior ${ }^{4}$ \\ Rodrigo Guimarães dos Santos Almeida ${ }^{1}$ \\ César Eduardo Pedersoli ${ }^{5}$
}

\begin{abstract}
Objective: to identify in the literature the gains health students and professionals perceive when using clinical simulation with dramatization resources. Method: integrative literature review, using the method proposed by the Joanna Briggs Institute (JBI). A search was undertaken in the following databases: Latin American and Caribbean Health Sciences Literature, Web of Science, National Library of Medicine, Cumulative Index to Nursing and Allied Health Literature, The Cochrane Library, Scopus, Scientific Electronic Library Online. Results: 53 studies were analyzed, which complied with the established inclusion criteria. Among the different gains obtained, satisfaction, self-confidence, knowledge, empathy, realism, reduced level of anxiety, comfort, communication, motivation, capacity for reflection and critical thinking and teamwork stand out. Conclusion: the evidence demonstrates the great possibilities to use dramatization in the context of clinical simulation, with gains in the different health areas, as well as interprofessional gains.

Descriptors: Students; Role Playing; Patient Simulation; Education; Perception.
\end{abstract}

\footnotetext{
Doctoral student, Escola de Enfermagem de Ribeirão Preto, Universidade de São Paulo, PAHO/WHO Collaborating Centre for Nursing Research Development, Ribeirão Preto, SP, Brazil.

${ }^{2} \mathrm{PhD}$, Associate Professor, Escola de Enfermagem de Ribeirão Preto, Universidade de São Paulo, PAHO/WHO Collaborating Centre for Nursing Research Development, Ribeirão Preto, SP, Brazil.

3 PhD, Professor, Escola Superior de Enfermagem de Coimbra, Coimbra, Portugal.

${ }^{4} \mathrm{PhD}$, Professor, Faculdade de Medicina de Ribeirão Preto, Universidade de São Paulo, Ribeirão Preto, SP, Brazil.

${ }^{5}$ PhD, Adjunct Professor, Universidade de Ribeirão Preto, Ribeirão Preto, SP, Brazil.
}

How to cite this article

Negri EC, Mazzo A, Martins JCA, Pereira Junior GA, Almeida RGS, Pedersoli CE. Clinical simulation with dramatization: gains perceived by students and health professionals. Rev. Latino-Am. Enfermagem. 2017;25:e2916. [Access Available in: DOI: http://dx.doi.org/10.1590/1518-8345.1807.2916. 


\section{Introduction}

As a result of the needs of a globalized society, immersed in Information and Communication Technologies (ICT) and going through a continuous process of scientific and technological modernization, teaching in health and nursing has undergone transformations, adapting competencies, critical thinking and decision making skills ${ }^{(1-3)}$.

To satisfy these needs, the professional education underwent restructuring, which has slowly provoked the evolution of knowledge and complex thinking, aiming to prepare more critical and reflexive professionals, capable of acting in a wide range of situations. In that context, the teaching institutions have reconsidered the educational practices and employed innovative strategies, with a view to stimulating competent professionals, which has highlighted the use of clinical simulation as a necessary and valued tool in the teaching-learning process ${ }^{(1-4)}$.

The act of teaching through clinical simulation has frequently been part of the undergraduate curriculum, and also of health professionals' training. Nevertheless, as a result of the advances in the structuring of the strategy and the increased capacity to gain competencies, critical reasoning, decision making and teamwork and to strengthen the professionals' self-confidence, it has been increasingly valued and enhanced as a teaching strategy $\mathrm{y}^{(5-8)}$.

In simulated clinical practice, several resources can be used, ranging from dramatization to the use of inanimate anatomic pieces and/or advanced simulators, which incorporate high computer and robotic technology and lead to many interaction possibilities, with great variation in the costs involved. In the construction of the simulated scenarios, physical and material resources are employed that approach the actual activities of clinical practice involving patients with a high degree of realism. The resources are defined according to the learning objectives and are classified according to their technological potentials $\mathbf{s}^{(6,9)}$.

Among the resources applied in this study, the dramatization technique will be highlighted. Dramatization can be defined as a theatre representation, determined based on a focus or theme. This resource grants meanings and permits the contents taught to be experienced in a context similar to those experienced in the actual practice ${ }^{(10)}$. Dramatization allows the student to integrate theory and practice, it is flexible and adjustable to different contexts, permits experiencing different perspectives and viewpoints and offers the student the opportunity to explore the individual vulnerability in a safe environment ${ }^{(11)}$.
In dramatization, the techniques explored can be role play and the use of simulated patients, mixed models and standardized patients.

Role play is the situation in which the learner, facilitator and/or instructor play different roles in the simulated scenario as if they were taking part in a clinical case, for the purpose of teaching and training(10). This strategy grants learning opportunities, involving both the student's affective and cognitive process, as they permit experiencing feelings, such as the experience of the patient's and other professionals' roles $^{(12)}$.

Educators and clinical simulation researchers frequently use the expressions "simulated patient" and "standardized patient" interchangeably or as synonyms in the literature, although differences exist between them. Simulated patients are trained individuals and/ or actors who play a role, exhibiting a story within the simulation for the purpose of teaching or assessment ${ }^{(13)}$.

The term standardized patient can be defined as: a member of the community (child, adolescent, adult, elderly) who agreed to play the role of a patient for a learning activity, through a legal contract with the teaching institution. The standardized patients do not play a role to perform the characteristics of another person or patient, but they answer any inquiry about the medical and social history based on their own lives ${ }^{(13)}$. This resource has served as a concrete possibility to provide clinical skills teaching and training, in function of its potential to comply with conditions closer to the ideal, guaranteeing the reliability of human interaction with communication and empathy(10). For ethical and legal reasons, this technique has not been much used in Brazil(14).

The mixed models enable the learner to develop technical and behavioral skills. They combine the simulated patient with a low-fidelity simulator to develop a specific activity in a scenario, such as an arm coupled to a student in a blood collection scenario for example (14-15). $^{\text {. }}$

Due to its reasonable cost and great application possibility, the use of simulated practices with dramatization resources can turn into an excellent ally for the qualification of professionals with critical and reflexive thinking, who are capable of reaching clinical judgments and making decisions. Nevertheless, to better use the technique, its use should be based on scientific evidences that demonstrate the positive or negative results of this teaching and learning strategy.

In that context, to better understand and employ the available resources related to the theme, the objective in this study was to identify, in the literature, the gains the health students and professionals perceived in the use of clinical simulation with dramatization resources. 


\section{Method}

An integrative review was undertaken, using the method of the Joanna Briggs Institute (JBI), which is focused on the feasibility, adequacy, significance and efficacy of the health interventions. This method can be used to map the main concepts that sustain a research area, as well as to clarify the operational definitions and/ or conceptual limits of a topic(16).

To construct the research question, the PICO strategy was used in the quantitative articles: P Students and professionals; I - Clinical simulation using dramatization; $\mathrm{O}$ - Perceived gains from clinical simulation using dramatization; and PICo in the qualitative articles PICo: P - Students and professionals; I - Clinical simulation and dramatization; Co - Perceived gains from clinical simulation using dramatization(17).

This strategy permitted formulating the following guiding question: What are the gains the health students and professionals perceive from the use of clinical simulation with dramatization resources?

Thus, after establishing the question, an initial search was undertaken in the portal PubMed (Public Medline) and in the database CINAHL (Cumulative Index to Nursing and Allied Health Literature), in order to identify the main descriptors and key words used in the studies that discussed the theme of interest in this review.

To answer the research question, the controlled and non-controlled descriptors were selected, related to each of the components of the PICO and PICo strategy, used according to the Health Sciences Descriptors (DEsCS) and Medical Subject Headings (MeSH).

The research was developed between June and December 2015 without any restrictions in terms of time, presentation or publication type, using the following controlled descriptors: Students; Role Playing; Patient Simulation; Education; Perception; and the non-controlled descriptors: Professional; Patients Standardized; Standardized Patient; Dramatization; Clinical Simulation; Experience. In between the descriptors, the following Boolean operators were considered: Students AND Professional AND Role Playing OR Patient Simulation OR Patients Standardized OR Standardized Patient OR Dramatization OR Clinical Simulation AND Education OR Perception OR Experience.

Inclusion and exclusion criteria were established for the research, considering a number of study types: 1) studies involving health students and professionals; 2) studies that discussed the theme simulation with dramatization, that is, role play, standardized patients, patient simulation, mixed patient; 3) studies with a quantitative and/or qualitative focus, which answered the question established, independently of the knowledge area they were linked to and 4) studies published in Portuguese, English and Spanish. Publications of opinions, consensus statements, retractions, editorials and experience reports were excluded.

To identify the studies, the following electronic databases were used: Latin American and Caribbean Health Sciences Literature (LILACS), Web of Science, National Library of Medicine (PubMed), Cumulative Index to Nursing and Allied Health Literature (CINAHL), The Cochrane Library, Scopus, Scientific Electronic Library Online (SciELO).

In total, 6,826 studies were found, which were moved to Web ENDNOTE. Of these, 1,414 were excluded because the studies had been published in more than one database, resulting in 5,412 studies. After reading the titles and abstracts of the 5,412 research articles, 5,103 were excluded because they did not answer the research question and 309 were selected to read the full article. Among the 309 studies analyzed, 53 were included in the research because they answered the question and because they complied with the inclusion criteria established.

Next, the research data were analyzed with the help of a tool the researchers had constructed, in accordance with the JBI instructions ${ }^{(16)}$, including: study title, authorship, journal, year of publication, place of study (country), research objective(s), methodological details, sample details, main outcomes and conclusions found. In the critical analysis of the selected articles, the research design was analyzed(18).

\section{Results}

Among the $53(100 \%)$ studies in the sample, the majority had been published in English. The studies had been mostly developed on the American $(n=27$, $50.94 \%)$, Asian $(n=9,17.0 \%)$, Oceania $(n=9,17.0 \%)$ and European continents $(n=8,15.1 \%)$.

When the type of dramatization the studies employed was analyzed, it was verified that 28 (52.9\%) used a simulated patient; $18(34.0 \%)$ role play; 4 $(7.5 \%)$ dramatization with standardized patient; 2 $(3.7 \%)$ simulated patient plus role play and 1 (1.9\%) mixed patient (simulated patient plus pelvis).

As demonstrated in Figure 1 , as regards the method used, among the studies analyzed, 23 were descriptive (43.4\%), 13 experimental (24.5\%), 8 quasiexperimental (15.1\%), 4 qualitative $(7.5 \%), 2$ mixed $(3.8 \%), 1$ cohort $(1.9 \%), 1$ multiple case study $(1.9 \%)$ and 1 (1.9\%) meta-analysis. The year of publication, type and number of participants have been described in Figure 1. 


\begin{tabular}{|c|c|c|c|}
\hline Year & Type of study and participants & Year & Type of study and participants \\
\hline $1999^{(19)}$ & $\begin{array}{l}\text { Experimental study } \\
75 \text { undergraduate students in medicine }\end{array}$ & $2012^{(45)}$ & $\begin{array}{l}\text { Experimental study } \\
44 \text { undergraduate students in nursing }\end{array}$ \\
\hline $2003^{(20)}$ & $\begin{array}{l}\text { Descriptive study } \\
45 \text { undergraduate students in veterinary sciences }\end{array}$ & $2012^{(46)}$ & $\begin{array}{l}\text { Experimental study } \\
106 \text { undergraduate students in medicine }\end{array}$ \\
\hline $2005^{(21)}$ & $\begin{array}{l}\text { Quasi-experimental study (pre and post-test) } \\
133 \text { undergraduate students in medicine, nursing and } \\
\text { pharmaceutical sciences }\end{array}$ & $2012^{(47)}$ & $\begin{array}{l}\text { Experimental study } \\
56 \text { undergraduate students in medicine }\end{array}$ \\
\hline $2005^{(22)}$ & $\begin{array}{l}\text { Quasi-experimental study } \\
17 \text { oncology physicians }\end{array}$ & $2012^{(48)}$ & $\begin{array}{l}\text { Experimental research (pre and post-test) } \\
31 \text { undergraduate students in dentistry }\end{array}$ \\
\hline $2006^{(23)}$ & $\begin{array}{l}\text { Descriptive pilot-study } \\
28 \text { graduate students in nursing (family, psychiatry, } \\
\text { geriatric) }\end{array}$ & $2012^{(49)}$ & $\begin{array}{l}\text { Experimental study } \\
108 \text { undergraduate students in nursing }\end{array}$ \\
\hline $2006^{(24)}$ & $\begin{array}{l}\text { Descriptive study } \\
136 \text { undergraduate students in medicine }\end{array}$ & $2012^{(50)}$ & $\begin{array}{l}\text { Descriptive study } \\
\text { Undergraduate students in medicine (not described) }\end{array}$ \\
\hline $2007^{(25)}$ & $\begin{array}{l}\text { Descriptive study } \\
284 \text { undergraduate students in medicine }\end{array}$ & $2012^{(51)}$ & $\begin{array}{l}\text { Qualitative and descriptive study } \\
11 \text { undergraduate students in nursing }\end{array}$ \\
\hline $2008^{(26)}$ & $\begin{array}{l}\text { Cohort study } \\
35 \text { undergraduate students in physiotherapy }\end{array}$ & $2012^{(52)}$ & $\begin{array}{l}\text { Descriptive study } \\
101 \text { undergraduate students in dentistry, medicine, nursing, } \\
\text { physiotherapy and pharmaceutical sciences }\end{array}$ \\
\hline $2008^{(27)}$ & $\begin{array}{l}\text { Descriptive study } \\
140 \text { undergraduate students in medicine }\end{array}$ & $2013^{(53)}$ & $\begin{array}{l}\text { Experimental study (post-test) } \\
154 \text { undergraduate students in pharmaceutical sciences }\end{array}$ \\
\hline $2008^{(28)}$ & $\begin{array}{l}\text { Quasi-experimental study (pre and post-test) } \\
19 \text { undergraduate students in medicine }\end{array}$ & $2013^{(54)}$ & $\begin{array}{l}\text { Descriptive study } \\
43 \text { undergraduate students in medicine }\end{array}$ \\
\hline $2009^{(29)}$ & $\begin{array}{l}\text { Qualitative study using focus group } \\
60 \text { undergraduate students in medicine }\end{array}$ & $2013^{(55)}$ & $\begin{array}{l}\text { Experimental study } \\
26 \text { undergraduate students in nursing }\end{array}$ \\
\hline $2009^{(30)}$ & $\begin{array}{l}\text { Descriptive study } \\
112 \text { undergraduate students in nursing }\end{array}$ & $2013^{(56)}$ & $\begin{array}{l}\text { Descriptive study } \\
29 \text { graduate students in audiology }\end{array}$ \\
\hline $2009^{(31)}$ & $\begin{array}{l}\text { Descriptive study } \\
8 \text { health professionals (nurses and physicians) }\end{array}$ & $2013^{(57)}$ & $\begin{array}{l}\text { Descriptive study } \\
27 \text { undergraduate students in pharmaceutical sciences }\end{array}$ \\
\hline $2010^{(12)}$ & $\begin{array}{l}\text { Multiple case study } \\
17 \text { undergraduate students in nursing }\end{array}$ & $2013^{(58)}$ & $\begin{array}{l}\text { Descriptive study } \\
15 \text { residents in medicine }\end{array}$ \\
\hline $2010^{(32)}$ & $\begin{array}{l}\text { Experimental research (pre and post-test) } \\
69 \text { undergraduate students in medicine }\end{array}$ & $2014^{(59)}$ & $\begin{array}{l}\text { Quasi-experimental study (pre and post-test) } \\
124 \text { fourth-year undergraduate students in medicine and } 123 \text { sixth- } \\
\text { year undergraduate students in medicine }\end{array}$ \\
\hline $2010^{(33)}$ & $\begin{array}{l}\text { Quasi-experimental study } \\
53 \text { undergraduate students in medicine }\end{array}$ & $2014^{(60)}$ & $\begin{array}{l}\text { Descriptive study } \\
202 \text { junior undergraduate students in physiotherapy and } \\
51 \text { senior undergraduate students in physiotherapy }\end{array}$ \\
\hline $2010^{(34)}$ & $\begin{array}{l}\text { Experimental research } \\
24 \text { undergraduate students in medicine }\end{array}$ & $2014^{(61)}$ & $\begin{array}{l}\text { Experimental research (pre and post-test) } \\
94 \text { undergraduate students in dentistry }\end{array}$ \\
\hline $2010^{(35)}$ & $\begin{array}{l}\text { Experimental study (pre and post-test) } \\
35 \text { undergraduate students in medicine }\end{array}$ & $2014^{(62)}$ & $\begin{array}{l}\text { Mixed study (quantitative and qualitative) } \\
144 \text { undergraduate students in nursing }\end{array}$ \\
\hline $2011^{(36)}$ & $\begin{array}{l}\text { Experimental research } \\
72 \text { health professionals (physician and nurses) }\end{array}$ & $2014^{(63)}$ & $\begin{array}{l}\text { Quasi-experimental study (pre and post-test) } \\
69 \text { undergraduate students in nursing }\end{array}$ \\
\hline $2011^{(37)}$ & $\begin{array}{l}\text { Mixed descriptive longitudinal and qualitative study using } \\
\text { focus group } \\
97 \text { oncologists }\end{array}$ & $2014^{(64)}$ & $\begin{array}{l}\text { Descriptive study } \\
47 \text { undergraduate students in nursing }\end{array}$ \\
\hline $2011^{(38)}$ & $\begin{array}{l}\text { Descriptive study } \\
65 \text { undergraduate students in medicine }\end{array}$ & $2014^{(65)}$ & $\begin{array}{l}\text { Qualitative study } \\
46 \text { undergraduate students in pharmacy and nursing }\end{array}$ \\
\hline $2011^{(39)}$ & $\begin{array}{l}\text { Descriptive study } \\
25 \text { health professionals (physicians, nurses, clinical } \\
\text { psychologists and physiotherapists) }\end{array}$ & $2014^{(66)}$ & $\begin{array}{l}\text { Qualitative and descriptive research } \\
15 \text { undergraduate students in nursing }\end{array}$ \\
\hline $2011^{(40)}$ & $\begin{array}{l}\text { Descriptive study } \\
27 \text { undergraduate students in radiology }\end{array}$ & $2015^{(67)}$ & $\begin{array}{l}\text { Descriptive study } \\
19 \text { residents in medicine }\end{array}$ \\
\hline $2011^{(41)}$ & $\begin{array}{l}\text { Descriptive study } \\
42 \text { undergraduate students in medicine }\end{array}$ & $2015^{(68)}$ & $\begin{array}{l}\text { Meta-analysis } \\
18 \text { articles ( } 4 \text { randomized and } 14 \text { non-randomized) }\end{array}$ \\
\hline $2011^{(42)}$ & $\begin{array}{l}\text { Descriptive study } \\
259 \text { undergraduate students in pharmaceutical sciences }\end{array}$ & $2015^{(69)}$ & $\begin{array}{l}\text { Descriptive study } \\
107 \text { undergraduate students in medicine }\end{array}$ \\
\hline $2012^{(43)}$ & $\begin{array}{l}\text { Quasi-experimental study (post-test) } \\
205 \text { undergraduate students in medicine }\end{array}$ & $2015^{(70)}$ & $\begin{array}{l}\text { Descriptive study } \\
158 \text { undergraduate students in nursing }\end{array}$ \\
\hline $2012^{(44)}$ & $\begin{array}{l}\text { Quasi-experimental study (pre and post-test) } \\
97 \text { residents in medicine }\end{array}$ & & \\
\hline
\end{tabular}

Figure 1 - Method, year of publication, type and number of participants, 2016 


\begin{tabular}{|c|c|}
\hline Perceived gains by health students and professionals & f \\
\hline Communication skills and competency ${ }^{(20,22,24,25-27,31-32,34,37,39,40,42-44,46,48,50,55-58,60-61,65-68)}$ & 28 \\
\hline Satisfaction with learning strategy ${ }^{(19,27,30,32,36,38,40-41,43-45,52-53,55,60,62,64,67,69-70)}$ & 20 \\
\hline Learning/knowledge $\mathrm{e}^{(23,28,30,35,36,41,43,50,54,57,60-61,64,68,70)}$ & 15 \\
\hline Clinical skills (anamnesis, physical examination, clinical procedures) $)^{(23,33,38,41,46-47,49,54,69-70)}$ & 10 \\
\hline Empathy $(29,59,65,66-67,69)$ & 6 \\
\hline Self-confidence ${ }^{(36,51,62,64,69)}$ & 5 \\
\hline Teamwork $^{(21,52,54,57)}$ & 4 \\
\hline Realism of the simulation $(38,58,63,65)$ & 4 \\
\hline Critical thinking ${ }^{(12,30,62,68)}$ & 4 \\
\hline Reduction of anxiety level $(26,47,63)$ & 3 \\
\hline Motivation for learning ${ }^{(25,37,68)}$ & 3 \\
\hline Capacity to use background knowledge ${ }^{(20,62)}$ & 2 \\
\hline Opportunity to reflect on the practice ${ }^{(37)}$ & 1 \\
\hline
\end{tabular}

*More than one perceived gain per article.

Figure 2 - Perceived gains by students and professionals using dramatization resources and frequency, 2016

\section{Discussion}

Simulation has turned into a fundamental tool for the education and recycling of health professionals. It permits modeling clinical events in a safe environment, resulting in learning gains due to the possibility for the student to develop competencies, critical reasoning, decision making, teamwork and, mainly, to contribute to the strengthening of self-confidence ${ }^{(5-8)}$.

Simulation with dramatization resources has been used as a teaching strategy through clinical simulation, in the education of future professionals as well as in the training of active ones. When applied as such, it is able to offer the students the possibility to train skills and even competencies at a reasonable cost, in a safe environment, through the creation of scenarios with a wide range of complexities. In addition, it realistically reproduces an encounter with the (simulated) patient, which can strongly contribute to the learning objectives outlined $^{(71)}$. It also offers the possibility of feedback by the simulated patient, which contributes and enriches the teaching-learning process ${ }^{(55)}$.

This study was aimed at identifying the gains health students and professionals perceived in clinical simulation using dramatization resources. Although the grey literature was not included, which can be considered a limiting factor, a large number of studies could be identified, observing that simulation with dramatization resources has been used expressive and effectively in the teaching and training process of health professionals in a wide range of scientific areas, also aiming to develop interprofessional competencies (Figure 1 and Figure 2).

The dramatization strategy used needs to support the learning objectives of the activity. Different dramatization strategies were employed in the studies assessed; among these, the use of the simulated patient and role play stood out.

The simulated patient participates actively in the activity and, in the debriefing process, permits interactivity in the learner's reflection. In addition, the patient needs to be engaged in the assessment of the activity. The use of the role play strategy allows the learner to empathetically experience the role of the patient, relative and/or of another professional, in an active, involving and dynamic manner, supporting the construction process of clinical competencies and effective communication. Clinical competence is a fundamental quality for professionals who are apt and capable of delivering high-quality care. The use of simulation can be considered an admirable tool for the students to find their action sphere, autonomy, adaptation and flexibility in the course of their development, in different realities ${ }^{(72)}$.

Among the gains identified in the studies analyzed, the enhancement of knowledge, development of empathy, of communication skills, satisfaction with the teaching-learning process, self-confidence, realism, reduction of the anxiety level, comfort, motivation to learn, capacity to reflect and think critically and teamwork skills were observed.

Communication was the gain that stood out in the studies analyzed. Health educators have been increasingly concerned with the inclusion of teachinglearning strategies for the development of communication skills, as effective communication is an essential clinical competency for the practice of health professions. It can be taught and qualified effectively by means of dramatization in simulated practices ${ }^{(20-21,25-27,29,31)}$. In the selected sample, the following dramatization strategies were widely used to develop communication: role play and simulated patient, mainly in situations that were 
difficult for the professionals to cope with, such as ethical dilemmas, communication of bad news, conflicts in the interprofessional team, among others(22,25,27,31,65-66).

Satisfaction with the clinical simulation method has been increasingly valued at health institutions and is related to the motivation process for learning ${ }^{(30)}$. It is an indicator of best practices in the teaching-learning process and of good work conditions for the educators. It can be influenced by the desire and experience of the teaching staff. In the studies analyzed, the use of simulated patients and the realism of the strategy were the main indicators of this perceived gain ${ }^{(45,73)}$.

The realism benefits the activity and makes it successful, as it makes the participants consider the strategy as legitimate and authentic $(32,38,58,63,65,74)$. During the simulation, the realism can be translated by the fidelity of the simulated experience in approaching the actual environment. High-fidelity simulation approaches the practice with patients as closely as possible ${ }^{(75)}$. In the sample, the studies analyzed demonstrated that the learners perceived the use of the simulated patient as very close to the real patients. In addition, the following also contributed to the realism: the extent to which the environment approaches the facilities in practice, as well as the educators' knowledge and preparation to trigger the emotions ${ }^{(19,58,63,65,76)}$. An environment close to the reality provokes the same psychological reactions in the individuals as they would have in practice, which makes the learners develop critical thinking and the decisionmaking skills required in an actual clinical scenario(5,77-78).

What the teaching-learning process, knowledge and critical thinking are concerned, simulation with dramatization showed to be an innovative and diversified teaching-learning tool, which promotes the students' opportunities to reflect on the practice ${ }^{(37)}$, strengthen the background knowledge $(22,35,41,50,54,56)$, understand the strong and weak points of their learning ${ }^{(60)}$, develop critical thinking ${ }^{(37,62)}$ and the opportunity to use previously acquired knowledge and skills(62) and, therefore, enhances the awareness on the students' actual capacities. In the studies observed, role play showed to be an interesting tool in the teaching-learning process $^{(25)}$, in view of the learners' level of acceptance ${ }^{(32)}$, as it makes the theoretical and practical knowledge significant, integrates and transforms it at the individual and collective levels ${ }^{(21,28)}$. It is also important to highlight that the simulated practices permit measuring and assessing the results obtained through instruments and/ or video recordings for future clarifications(58).

The studies also demonstrated that the simulations made the learners more trusting, minimizing the fear to undertake the procedures with the patients $(20,26,30)$, mainly in the physical examination and communication

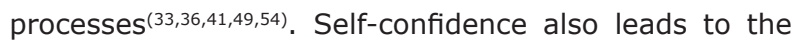
reduction of the anxiety level $(26,44,47,63)$ and increased comfort $(44,47)$.

Anxiety is a natural reaction, produced in response to certain situations in which the person needs adaptive resources. When confronted with critical activities for which they do not feel prepared, the learners report anxiety, tension, mainly when the care targets children and patients in severe and/or terminal conditions ${ }^{(79)}$. The stress and anxiety can negatively contribute and interfere in the teaching-learning process. The two main sources of anxiety in clinical practice are lack of knowledge and lack of skills ${ }^{(79)}$.

In the gains the learners perceived, the development of empathy could be observed, which involves the feeling of sensitization for the changes the other person feels and reflects moment by moment ${ }^{(80)}$. Empathy was a gain perceived in some studies analyzed $(29,59,66-67,69)$ and measured during the role play strategy ${ }^{(69)}$.

It is important to highlight that, in technical competency development, the dramatization comes with some limitations, as not all procedures can be executed on the simulated patients. To solve that difficulty, sometimes, mixed patients are used, like when a pelvis is attached to the simulated patient during urinary catheterization. In the sample of this review, it could be identified that simulation with dramatization was used in anamnesis ${ }^{(46)}$, physical examination ${ }^{(19,38)}$, pelvic examination ${ }^{(23,33,47,49)}$ and postoperative pain assessment skills ${ }^{(36)}$. It was also observed that dramatization was used to develop critical thinking in punctual $(30,35,62,68)$ studies, perhaps due to the fact that the physiological outcomes cannot be controlled in simulated patients.

\section{Conclusion}

The large number of studies found in this research demonstrates that simulation with dramatization is a tool in the teaching-learning process, largely used in the education and qualification of health professionals.

In this process, in a wide range of health areas and also involving different professionals, different gains are obtained, among which satisfaction, self-confidence, knowledge, empathy, realism, reduced anxiety, comfort, communication, motivation, capacity to reflect and think critically and teamwork stand out. The evidences demonstrate the great possibility to use dramatization in the clinical simulation context.

\section{References}

1. Carvalho EC. Challenges in nursing competency development. Rev. Latino-Am. Enfermagem. 2008 
Oct;16(5):801-2. doi: http://dx.doi.org/10.1590/ S0104-11692008000500001

2. Silva MG, Fernandes JD, Teixeira GAS, Silva RMO. Processo de formação da(o) enfermeira(o) na contemporaneidade: desafios e perspectivas. Texto Contexto Enferm. 2010 Mar;19(1):176-84. doi: http:// dx.doi.org/10.1590/S0104-07072010000100021.

3. Teixeira CRS, Kusumota L, Braga FTMM, Gaioso VP, Santos CB, Silva VLS, et al. O uso de simulador no ensino de avaliação clínica em enfermagem. Texto Contexto Enferm. 2011; 20(spe):187-93. doi: http:// dx.doi.org/10.1590/S0104-07072011000500024.

4. Marmol MT, Braga FTMM, Garbin LM, Moreli L, Santos CB, Carvalho EC. Central catheter dressing in a simulator: the effects of tutor's assistance or selflearning tutorial. Rev. Latino-Am. Enfermagem. 2012 Dec;20(6):1134-41. doi: http://dx.doi.org/10.1590/ S0104-11692012000600016.

5. Berragan L. Simulation: an effective pedagogical approach for nursing? Nurse Educ Today. 2011;31(7):660-3. doi: http://dx.doi.org/10.1016/j. nedt.2011.01.019

6. Martins JCA, Mazzo A, Baptista RCN, Coutinho VRD, Godoy S, Mendes IAC, et al. The simulated clinical experience in nursing education: a historical review. Acta Paul Enferm. 2012;25(4):619-25. doi: http:// dx.doi.org/10.1590/S0103-21002012000400022.

7. Bensfield LA, Olech MJ, Horsley TL. Simulation for highstakes evaluation in nursing. Nurse Educ. 2012;37(2):714. doi: 10.1097/NNE.0b013e3182461b8c

8. Christian A, Krumwiede N. Simulation enhances self-efficacy in the management of preeclampsia and eclampsia in obstetrical staff nurses. Clin Simul Nurs. 2013;9(9):369-77. doi: http://dx.doi.org/10.1016/j. ecns.2012.05.006

9. Sohn M, Ahn Y, Park H, Lee M. Simulationbased smoking cessation intervention education for undergraduate nursing students. Nurse Educ Today. 2012;32(8):868-72. doi: 10.1016/j.nedt.2011.11.005

10. Bonamigo EL, Destefani AS. A dramatização como estratégia de ensino da comunicação de más notícias ao paciente durante a graduação médica. Rev Bioet. [Internet]. 2010 [acesso $18 \mathrm{fev} \mathrm{2016];18(3):725-42.}$ Disponível em: http://migre.me/uFBOI

11. Arveklev SH, Wigert $\mathrm{H}$, Berg L, Burton B, Lepp M. The use and application of drama in nursing educationan integrative review of the literature. Nurse Educ Today. 2015 Jul; 35(7):e12-7. doi: 10.1016/j.nedt.2015.02.025 12. Ertmer P, Strobel J, Cheng X, Chen X, Kim H, Olesova $L$, et al. Expressions of critical thinking in role-playing simulations: Comparisons across roles. J Comput in Higher Educ. 2010;22:73-94. doi: 10.1007/s12528010-9030-7
13. Churchose C, Mccafferty C. Standardized patients versus simulated patients: Is there a diference? Clin Simul Nurs. 2012;8(8):363-5. doi: http://dx.doi. org/10.1016/j.ecns.2011.04.008

14. Mazzo A. Impacto da simulação na satisfação e na autoconfiança do estudante na assistência de enfermagem na retenção urinária [Tese de Livre Docência]. Ribeirão Preto (SP): Escola de Enfermagem de Ribeirão Preto da Universidade de São Paulo; 2014. $60 \mathrm{p}$.

15. Weller JM, Nestel D, Marshall SD, Brooks PM, Conn JJ. Simulation in clinical teaching and learning. Med J Aust. 2012 May;196(9):594. doi: 10.5694/mja10.11474 16. Joanna Briggs Institute. Joanna Briggs Reviewers' Manual: 2014 edition. [cited Mar 12, 2016]; Available from: http://joannabriggs.org/assets/docs/sumari/ ReviewersManual-2014.pdf

17. Santos CMC, Pimenta CAM, Nobre MRC. The pico strategy for the research question construction and evidence search. Rev. Latino-Am. Enfermagem. 2007. [cited Mar 10, 2016];15(3). Available from: http://www. scielo.br/pdf/rlae/v15n3/pt_v15n3a23.pdf

18. Polit DF, Beck CT. Fundamentos de pesquisa em enfermagem: avaliação de evidência para a prática de enfermagem. 7th.ed. Porto Alegre: Artmed; 2011.

19. McGraw RC, O'Connor HM. Standardized patients in the early acquisition of clinical skills. Med Educ. 1999 Aug;33(8):572-8. doi: 10.1046/j.13652923.1999.00381.x

20. Radford AD, Stockley P, Taylor IR, Turner R, Gaskell $\mathrm{C}$, Kaney $\mathrm{S}$, et al. Use of simulated clients in training veterinary undergraduates in communication skills. Vet Rec. 2003 Apr 5;152(14):422-7. doi:10.1136/ vr.152.14.422

21. Curran VR, Mugford JG, Law RM, MacDonald S. Influence of an interprofessional HIV/AIDS education program on role perception, attitudes and teamwork skills of undergraduate health sciences students. Educ Health. (Abingdon). 2005 Mar;18(1):32-44. doi: 10.1080/13576280500042606

22. Lenzi R, Baile $W F$, Berek J, Back A, Buckman $R$, Cohen $L$, et al. Design, conduct and evaluation of a communication course for oncology fellows. J Cancer Educ. 2005;20(3):143-9. doi: 10.1207/ s15430154jce2003_7

23. Theroux R, Pearce C. Graduate students' experiences with standardized patients as adjuncts for teaching pelvic examinations. J Am Acad Nurse Pract. 2006 Sep;18(9):429-35. doi: 10.1111/j.17457599.2006.00158.x

24. McGovern MM, Johnston M, Brown K, Zinberg $R$, Cohen D. Use of standardized patients in, undergraduate medical genetics education. Teach 
Learn Med. 2006 Summer;18(3):203-7. doi: 10.1207/ s15328015tIm1803_3

25. Nestel D, Tierney T. Role-play for medical students learning about communication: guidelines for maximising benefits. BMC Med Educ. 2007 Mar 2;7:3. doi: 10.1186/1472-6920-7-3

26. Lewis M, Bell J, Asghar A. Use of simulated patients in development of physiotherapy students' interpersonal skills. Int J Ther Rehabil. 2008 May;15(5):221-7. doi: http://dx.doi.org/10.12968/ijtr.2008.15.5.29234

27. Baer AN, Freer JP, Milling DA, Potter WR, Ruchlin $\mathrm{H}$, Zinnerstrom $\mathrm{KH}$. Breaking bad news: use of cancer survivors in role-playing exercises. J Palliat Med. 2008 Jul;11(6):885-92. doi: 10.1089/jpm.2007.0253

28. McIlvried DE, Prucka SK, Herbst M, Barger C, Robin $\mathrm{NH}$. The use of role-play to enhance medical student understanding of genetic counseling. Genet Med. 2008 Oct;10(10):739-44. doi: 10.1097/ GIM.0b013e318187762e

29. Aragão JCS, Silveira CO, Hungria MM, Oliveira MP. $O$ uso da técnica de role-playing como sensibilização dos alunos de Medicina para o exame ginecológico. Rev Bras Educ Med. 2009;33(1):80-3. doi:http://dx.doi. org/10.1590/S0100-55022009000100011.

30. Robinson-Smith G, Bradley PK, Meakim C. Evaluating the Use of Standardized Patients in Undergraduate Psychiatric Nursing Experiences. Clin Simul Nurs. 2009;5(6):203-11. doi: http://dx.doi.org/10.1016/j. ecns.2009.07.001

31. Eid A, Petty M, Hutchins L, Thompson R. "Breaking bad news": standardized patient intervention improves communication skills for hematology-oncology fellows and advanced practice nurses. J Cancer Educ. 2009;24(2):154-9. doi: 10.1080/08858190902854848

32. Bosse HM, Nickel M, Huwendiek S, Jünger J, Schultz $\mathrm{JH}$, Nikendei C. Peer role-play and standardised patients in communication training: a comparative study on the student perspective on acceptability, realism, and perceived effect. BMC Med Educ. 2010 Mar 31;10(27): 19. doi: 10.1186/1472-6920-10-27

33. Wånggren $K$, Fianu Jonassen $A$, Andersson $S$, Pettersson G, Gemzell-Danielsson K. Teaching pelvic examination technique using professional patients: a controlled study evaluating students' skills. Acta Obstet Gynecol Scand. 2010 Oct;89(10):1298-303. doi: 10.3109/00016349.2010.501855

34. Siassakos D, Draycott T, O'Brien K, Kenyon C, Bartlett C, Fox R. Exploratory randomized controlled trial of hybrid obstetric simulation training for undergraduate students. Simul Healthc. 2010 Aug;5(4):193-8. doi: 10.1097/SIH.0b013e3181d3ee0b.

35. Spollen JJ, Thrush CR, Mui DV, Woods MB, Tariq SG, Hicks E. A randomized controlled trial of behavior change counseling education for medical students. Med Teach. 2010;32(4):e170-7. doi: 10.3109/01421590903514614.

36. McGillion M, Dubrowski A, Stremler R, Watt-Watson J, Campbell F, McCartney C, et al. The Postoperative Pain Assessment Skills pilot trial. Pain Res Manage [Internet]. 2011 [cited May 10, 2016] Nov-Dec;16(6):433-9. Available from: http://dx.doi.org/10.1155/2011/278397 37. Dunlop KL, Barlow-Stewart K, Butow P, Heinrich P. A model of professional development for practicing genetic counselors: adaptation of communication skills training in oncology. J Genet Couns. 2011 Jun;20(3):217-30. doi: 10.1007/s10897-010-9340-y.

38. Langen $W H$, Hanson D, Fien R, Parkhurst D. The evaluation of physician assistant students' historytaking abilities using actors as standardized patients. J Physician Assist Educ. [Internet]. 2011 [cited Mar 10, 2016];22(4):34-7. Available from: http://migre.me/ uGM82

39. Carvalho IP, Pais VG, Almeida SS, Ribeiro-Silva R, Figueiredo-Braga $M$, Teles $A$, et al. Learning clinical communication skills: outcomes of a program for professional practitioners. Patient Educ Couns. 2011 Jul;84(1):84-9. doi: 10.1016/j.pec.2010.05.010.

40. Halkett GKB, Mckay J, Shaw T. Improving students' confidence levels in communicating with patients and introducing students to the importance of history taking. Radiography. 2011;17(1):55-60. doi: http://dx.doi. org/10.1016/j.radi.2010.02.006

41. Sutin D, Rolita L, Yeboah N, Taffel L, Zabar S. A novel longitudinal geriatric medical student experience: using teaching objective structured clinical examinations. J Am Geriatr Soc. 2011 Sep;59(9):1739-43. doi: 10.1111/j.1532-5415.2011.03538.x

42. Rao D. Skills Development Using Role-Play in a FirstYear Pharmacy Practice Course. Am J Pharm Educ. 2011 Jun 10;75(5):84. doi: 10.5688/ajpe75584

43. Rodríguez-Díez MC, Beunza JJ, López-Del BC, Hyder O, Civeira-Murillo MP, Díez N. Aprendizaje de la historia clínica con pacientes simulados en el grado de Medicina. Educ Méd. [Internet]. 2012 Mar [acceso 10 mayo 2016];15(1):47-52. Disponible en: http://migre. me/uGMu6

44. Jameel A, Noor SM, Ayub S. Survey on perceptions and skills amongst postgraduate residents regarding breaking bad news at teaching hospitals in Peshawar, Pakistan. J Pak Med Assoc. [Internet]. 2012 [cited May 10, 2016] Jun;62(6):585-9. Available from: http:// migre.me/uGMAG

45. Luctkar-Flude $M$, Wilson-Keates $B$, Larocque M. Evaluating high-fidelity human simulators and standardized patients in an undergraduate nursing 
health assessment course. Nurse Educ Today. 2012 May;2(4):448-52. doi: 10.1016/j.nedt.2011.04.011.

46. Elley CR, Clinick T, Wong C, Arroll B, Kennelly J, Doerr $H$, et al. Effectiveness of simulated clinical teaching in general practice: randomised controlled trial. J Prim Health Care. 2012 Dec 1;4(4):281-7. doi:10.1071/ HC12281

47. Khadivzadeh T, Erfanian F. The effects of simulated patients and simulated gynecologic models on student anxiety in providing IUD services. Simul Healthc. 2012 Oct;7(5):282-7. doi: 10.1097/SIH.0b013e31826064b7. 48. Brame JL, Martin R, Tavoc T, Stein M, Curran AE. A randomized controlled trial of the effect of standardized patient scenarios on dental hygiene students' confidence in providing tobacco dependence counseling. J Dent Hyg. [Internet]. 2012 [cited Jun 10, 2016] Fall;86(4):28291. Available from: http://migre.me/uGN25.

49. Bornais JA, Raiger JE, Krahn RE, El-Masri MM. Evaluating undergraduate nursing students' learning using standardized patients. J Prof Nurs. 2012 SepOct;28(5):291-6. doi: 10.1016/j.profnurs.2012.02.001. 50. Kiluk JV, Dessureault S, Quinn G. Teaching medical students how to break bad news with standardized patients. J Cancer Educ. 2012 Jun;27(2):277-80. doi: 10.1007/s13187-012-0312-9.

51. Choi YJ. Exploring experiences of psychiatric nursing simulations using standardized patients for undergraduate students. Asian Nurs Res. 2012 Sep;6(3):91-5. doi:10.1016/j.anr.2012.07.001.

52. Wamsley M, Staves J, Kroon L, Topp K, Hossaini M, Newlin B, et al. The impact of an interprofessional standardized patient exercise on attitudes toward working in interprofessional teams. J Interprof Care. 2012 Jan;26(1):28-35. doi: 10.3109/13561820.2011.628425. 53. Grice GR, Wenger P, Brooks N, Berry TM. Comparison of patient simulation methods used in a physical assessment course. Am J Pharm Educ. 2013 May 13;77(4):77. doi: 10.5688/ajpe77477

54. Burgess A, Clark T, Chapman R, Mellis C. Medical student experience as simulated patients in the OSCE. Clin Teach. 2013 Aug;10(4):246-50. doi: 10.1111/ tct.12016.

55. Lin EC, Chen SL, Chao SY, Chen YC. Using standardized patient with immediate feedback and group discussion to teach interpersonal and communication skills to advanced practice nursing students. Nurse Educ Today. 2013 Jun;33(6):677-83. doi: 10.1016/j. nedt.2012.07.002.

56. Naeve-Velguth S, Christensen SA, Woods S. Simulated patients in audiology education: student reports. J Am Acad Audiol. 2013 Sep;24(8):740-6. doi: 10.3766/jaaa.24.8.10.
57. Katoue MG, Al Haqan A. Implementation and evaluation of a workshop on patient counseling about antidiabetic medications for final-year pharmacy students. Med Princ Pract. 2013;22(5):489-94. doi: 10.1159/000350840.

58. Harnof S, Hadani M, Ziv A, Berkenstadt H. Simulationbased interpersonal communication skills training for neurosurgical residents. Isr Med Assoc J. [Internet]. 2013 Sep [cited May 10, 2016];15(9):489-92. Available from: http://migre.me/uGNBm

59. Schweller M, Costa FO, Antônio MÂ, Amaral EM, Carvalho-Filho MA. The impact of simulated medical consultations on the empathy levels of students at one medical school. Acad Med. 2014 Apr;89(4):632-7. doi: 10.1097/ACM.0000000000000175.

60. Mandrusiak A, Isles $R$, Chang A, Choy NL, Toppenberg $R$, McCook $D$, et al. Senior physiotherapy students as standardised patients for junior students enhances self-efficacy and satisfaction in both junior and senior students. BMC Med Educ. 2014;14(5):105. doi: 10.1186/1472-6920-14-105

61. Singleton JA, Carrico RM, Myers JA, Scott DA, Wilson RW, Worth CT. Tobacco cessation treatment education for dental students using standardized patients. J Dent Educ. [Internet]. 2014 [cited May 10, 2016] Jun;78(6):895-905. Available from: http://migre.me/ uGNKt

62. Wheeler CA, McNelis AM. Nursing student perceptions of a community-based home visit experienced by a roleplay simulation. Nurs Educ Perspect. [Internet]. 2014 [cited May 10, 2016] Jul-Aug;35(4):259-61. Available from: http://migre.me/uGNXh

63.Kameg KM, Szpak JL, Cline TW, McDermott DS. Utilization of standardized patients to decrease nursing student anxiety. Clin Simul Nurs. 2014;10(11):567-73. doi: http://dx.doi.org/10.1016/j.ecns.2014.09.006 64. Mills J, West C, Langtree T, Usher K, Henry R, Chamberlain-Salaun $\mathrm{J}$, et al. Putting it together: unfolding case studies and high-fidelity simulation in the first-year of an undergraduate nursing curriculum. Nurse Educ Pract. 2014 Jan;14(1):12-7. doi:10.1016/j. nepr.2013.06.003

65. Koo L, Layson-Wolf C, Brandt N, Hammersla M, Idzik S, Rocafort PT, et al. Qualitative evaluation of a standardized patient clinical simulation for nurse practitioner and pharmacy students. Nurse Educ Pract. 2014 Nov;14(6):740-6. doi: 10.1016/j. nepr.2014.10.005.

66. Mackey S, Tan KK, Ignacio J, Palham S, Dawood RB, Liaw SY. The learning experiences of senior student nurses who take on the role of standardised patient: a focus group study. Nurse Educ Pract. 2014 Nov;14(6):692-7. doi: 10.1016/j.nepr.2014.10.003. 
67. Sittikariyakul $P$, Jaturapatporn D, Kirshen AJ. Acting as standardized patients enhances family medicine residents' self-reported skills in palliative care. Adv Health Sci Educ Theory Pract. 2015 Aug;20(3):645-54. doi: 10.1007/s10459-014-9552-2

68. Oh PJ, Jeon KD, Koh MS. The effects of simulationbased learning using standardized patients in nursing students: A meta-analysis. Nurse Educ Today. 2015 May;35(5):e6-e15. doi: 10.1016/j.nedt.2015.01.019.

69. King J, Hill K, Gleason A. All the world's a stage: evaluating psychiatry role-play based learning for medical students. Australas Psychiatry. 2015 Feb;23(1):76-9. doi: 10.1177/1039856214563846.

70. McNamara N. Preparing students for clinical placements: The student's perspective. Nurse Educ Pract. 2015 May;15(3):196-202. doi: 10.1016/j. nepr.2014.11.011.

71. Williams B, Song JJY. Are simulated patients effective in facilitating development of clinical competence for healthcare students? A scoping review. Adv Simul. 2016;1(6):3-9. doi: 10.1186/s41077-016-0006-1

72. Gonçalves R, Coutinho V, Lobão C. Simulação e desenvolvimento de competências.

In: Martins JCA, Mazzo A, Mendes IAC, Rodrigues MA. (Org.). A simulação no ensino de enfermagem. Ribeirão Preto: SOBRACEN; 2014.

73. Cantrell MJ, Deloney LA. Integration of standardized patients into simulation. Anesthesiol Clin. 2007 Jun;25(2):377-83. doi: 10.1016/j.anclin.2007.03.003

74. Baptista RCN, Martins JCA, Pereira MFCR, Mazzo A. Students' satisfaction with simulated clinical experiences: validation of an assessment scale. Rev. Latino-Am. Enfermagem. 2014 Oct;22(5):709-715. doi: http://dx.doi.org/10.1590/0104-1169.3295.2471.

75. Tun JK, Alinier G, Tang J, Kneebone RL. Redefining Simulation Fidelity for Healthcare Education. Simul Gaming. 2015 Apr;5(1). doi: 10.1177/1046878115576103

76. Jeffries PR. Simulation in nursing education: From conceptualization to evaluation. 2.ed. New York, NY: National League for Nursing; 2007.

77. Brady S, Bogossian F, Gibbons K. The effectiveness of varied levels of simulation fidelity on integrated performance of technical skills inmidwifery students-a randomised intervention trial. Nurse Educ Today. 2015 Mar;35(3):524-9. doi: 10.1016/j.nedt.2014.11.005.
78. Baptista RCN, Pereira MFCR, Martins JCA. Simulação no ensino de graduação em enfermagem: evidências científicas. In: Martins JCA, Mazzo A, Mendes IAC, Rodrigues MA, organizadores. A simulação no ensino de enfermagem, Ribeirão Preto: SOBRACEN; 2014. p. 6576.

79. Cremonese TS, Marques IR. Significados das primeiras experiências do estudante de enfermagem nos estágios clínicos. Rev Enferm UNISA. [Internet]. 2011 [acesso 14 ago 2016];12(2):94-9. Disponível em: http://migre.me/uGORL

80. Costa FD, Azevedo RCS. Empatia, relação médicopaciente e formação em medicina: um olhar qualitativo. Rev Bras educ med. 2010;34(2):261-9. doi: http:// dx.doi.org/10.1590/S0100-55022010000200010.
Received: Sept. $11^{\text {th }} 2016$ Accepted: May $2^{\text {nd }} 2017$
Corresponding Author:

Alessandra Mazzo

Universidade de São Paulo. Escola de Enfermagem de Ribeirão Preto

Av. dos Bandeirantes, 3900

Bairro: Monte Alegre

CEP: 14040-902, Ribeirão Preto, SP, Brasil

E-mail: amazzo@eerp.usp.br
Copyright $\odot 2017$ Revista Latino-Americana de Enfermagem This is an Open Access article distributed under the terms of the Creative Commons (CC BY).

This license lets others distribute, remix, tweak, and build upon your work, even commercially, as long as they credit you for the original creation. This is the most accommodating of licenses offered. Recommended for maximum dissemination and use of licensed materials. 